\title{
Student Voice, Citizenship and Regulated Spaces
}

\author{
Bronwyn Wood, Rowena Taylor and Rose Atkins
}

\section{Preprint version}

Wood, B. E., Taylor, R., \& Atkins, R. (2018). Student Voice, Citizenship and Regulated Spaces. In R. Bourke \& J. Loveridge (Eds.), Radical Collegiality through Student Voice: Educational Experience, Policy and Practice (pp. 179-196). Singapore: Springer Singapore.

\begin{abstract}
Student voice and youth citizenship participation programmes in school at times rest upon simplistic and naive assumptions of the hierarchies of power that are embedded in regulated spaces. Such assumptions can also result from the prevailing models of youth participation that often rely on oppositional notions of power between students and adults. In this chapter we critique these positions by interrogating the exchanges of power between secondary school students and teachers during the implementation of a participatory social studies curriculum project in which students took "personal social action' for assessment credits. Drawing on research with five schools in Aotearoa New Zealand involving classroom observations, student focus group interviews $(n=93)$, teacher interviews and collaborative research, we share two case studies which explore the influence students or teachers had on controlling the social action process. Our findings illustrate a highly dynamic and intergenerational process in which the locus of power continually moved between adults and students during the course of the social action process. The need for complex understandings of power-sharing is required if young people are to participate in student voice and citizenship action in the context of highly regulated school spaces.
\end{abstract}

Keywords: student voice, participation, agency, regulated spaces, partnership, citizenship

\section{Introduction}

Including the voices, perspectives, ideas, and rights of young people is a unifying theme of literature in both citizenship participation and student voice initiatives. Those advocating for greater youth citizenship participation and enhanced student voice share a belief that young people have rights and that these rights need to be honoured, protected, and advocated for in light of their perceived unequal status to adults in society (Cook-Sather 2014; Invernizzi and Williams 2008; Thomas and Percy-Smith 2010). They also hold a commitment to seeking to consult with, gain feedback from, and engage young people in their education (Cook-Sather 2014; Fielding 2004) and more broadly, across society. An underlying premise of citizenship and student voice research, policy, and practice is the commitment to recognise the rights of the child as portrayed in the United Nations Convention on the 
Rights of the Child [UNCRC] (Lundy 2007). Regarded by some as "unquestionably the most significant milestone for the development of current child polic ies" (Woodhead 2010, p. xx), the UNCRC provided a foundation for a new position of children in contemporary societies where their rights to both protection and participation were outlined clearly (Invernizzi and Williams 2008). The 'new' social studies of childhood developed by James et al. (1998) in their pivotal book Theorizing Childhood also set out a new agenda that viewed children as competent social actors in their own right. These shifts in thinking about and valuing the contributions of children were pivotal to the growing proliferation of citizenship participation and student voice initiatives that have emerged in many western nations since the 1990s.

Yet despite this momentum, the idea of children and young people participating as citizens remains highly contested. There are significant differences in how people define and enact youth participation, and wide variation in how nations interpret participation in their curriculum polic ies (Faulks 2000; Kennedy 2007; Nelson and Kerr 2006). Barber (2009) suggests that a notional spectrum of involvement from passive to active can be used when attempting to define participation, but this raises questions about how these concepts are defined and measured. In order to support teachers, educators, and others involved in enhancing the participation of young people in society, several models and typologies have been proposed for both student voice and citizenship participation work with children and young people. In this chapter, we begin by examining these as a starting point for a broader discussion on what it takes for young people to experience authentic, agentic, and meaningful experiences of participation and student voice in schools. This discussion forms the backdrop to our two-year study in five secondary schools in Aotearoa New Zealand in which we examined a curriculum and assessment initiative that required social studies students to take personal social action (New Zealand Qualification Authority [NZQA] n.d.). In this chapter we discuss how our examination of the process of senior secondary school students (aged between 15 and 18, in Years 11-13) taking social action highlighted the interrelational and intergenerational nature of student participation. Drawing on two case studies, we illustrate how student voice and citizenship participation needs to be understood as a dynamic and negotiated partnership of power-sharing between young people and adults within regulated sites and spaces. This analysis draws us to a much deeper reading of the models of participation frequently used in student voice and citizenship participation work in schools.

\section{Models of Participation and Student Voice}

Since the 1960s, several explanatory typologies have attempted to evaluate, measure, and address the complexity of youth participation. One of the earliest models was Sherry Arnstein's (1969) Ladder of Citizens' Participation. While not focused specifically on children and young people, Arnstein's graduated ladder - from 'manipulation' to 'citizen control'-was an early attempt to examine in whose interest participation serves. Drawing on this ladder metaphor, Roger Hart created one of the 
most well-known and widely used frameworks with children and young people-Hart's Ladder of Participation (1992). Specifically with children's participation in mind, Hart attempted to address the "strong tendency on the part of adults to underestimate the competence of children while using them in events to influence some cause" (p. 9).

Several other frameworks have been proposed that have adapted Hart's original ladder. To illustrate just some of these, we will describe five here which capture some of the variety of similarities and differences: (i) Treseder's (1997) Degrees of Participation-while this draws heavily on Hart's Ladder, Treseder reimagines the states of participation as five possibilities without hierarchy, thus abandoning the ladder metaphor; (ii) Shier's (2001) Levels of Participation shifts the focus onto structures that hinder or enable young people's participation. Shier also includes three stages of commitment by adults (openings, opportunities, and obligations) to demonstrate how such ideas could be implemented in institutions. ${ }^{1}$ More recent developments that use a similar continuum approach and apply this specifically to citizenship participation include: (iii) McLaughlin's (1992) minimalmaximal forms of citizenship; (iv) Thomson and Holdsworth's (2003) four-fold continuum of school participation with 'turning up' or 'taking part' at one end through to political action at the other; and (v) Westheimer and Kahne's (2004) well-known Kinds of Citizens model (personally responsible, participatory, and justice-oriented citizens). ${ }^{2}$ These models and typologies have proved influential in work related to young people's participation as active citizens (Barber 2009; Shier 2001).

Inspired by the same desire for greater student agency and participation as the models discussed above, student voice research in education specifically addresses issues of youth participation in schooling contexts and educational institutions. For example, Fielding's (2011) Patterns of Partnership describes seven types of partnership models in student voice work ranging from using students as data sources - at the minimal level - through to intergenerational learning as a 'lived democracy' at the maximal level. Fielding describes a lived democracy as having a shared commitment to the common good across a school community that also includes occasions of equal sharing of power and responsibility. In more recent work, Pearce and Wood (2016) developed an Evaluative Framework that identifies key attributes and principles of more transformative types of student voice work. Based on a systematic literature review of student voice research since 2011, Pearce and Wood identified four dominant types of student voice work-dialogical, intergenerational, collective, and transgressive - which they viewed as a series of building blocks resting upon dialogic approaches, and moving through collective, inclusive, and intergenerational processes to produce more transgressive outcomes. Each element in the framework relies to some extent on the others, with the student voice work likely to fall short of transformative goals should one of the elements be neglected.

\footnotetext{
${ }^{1}$ For a review of additional models of participation see https://360participation.com/models-of-participation/ and Mayes et al. (2017) Theories and images of power in student voice work https://ijs v.psu.edu/?article=whatcan-a-conception-of-power-do-theories-and-images-of-power-in-student-voice-work

${ }^{2}$ For a review of these latter three models see Wood et. al, 2013).
} 
These models provide an invaluable role in helping students, educators, community members, and governments to evaluate the nature of their youth participation programmes. However, the trouble with models that are presented as ladders or tables is that they can make concepts like participation and voice appear quite simplistic and linear. Indeed, it has the potential to abrogate the adult responsibility further away from including a child or young person simply because one can argue they are somewhere on the ladder. A simple reading of these models can foster a view that adults permit young people to participate (Wyness 2013) or give away some of their power in order to share it with young people. This can lead to the assumption that as long as adults make way for young people's participation, their participation is assumed. These models also imply that young people will have the ability to act as full citizens and feel empowered by this process. This suggests a rather normative and hierarchical notion of partic ipation that is based on an oppositional model of power in which adults are assumed to possess power and children are not (Gallagher 2008; Holt 2004). Such initiatives also assume a level playing field for all young people, with the idea that if the conditions are set up for their participation, all young people can participate equally. In addition, such models have been used to justify participatory approaches to research with children and young people that create a methodological hierarchy "in which 'good' - or perhaps 'best' - practice will be situated on the topmost rung (full participation), above less 'partic ipatory' projects" (Gallacher and Gallagher 2008, p. 501). Finally, these models often overlook the power imbalances in highly regulated spaces such as schools and include narrowly conceived notions of student voice and participation that rarely include the right to be transgressive (Pearce and Wood 2016; Skelton 2007; Wyness 2013).

Schools remain highly regulated sites for young people which further minimises the opportunity to practise participation (Mitra 2005; Robinson and Taylor 2013). Yet the pre-existing landscapes of power that operate in classrooms and schools are often overlooked or viewed quite simplistically when implementing student voice or participation initiatives. Critical and post-structural theorists both offer deeper insights into understanding how power operates within school settings. Critical theorists such as Bourdieu, Apple, and Giroux draw attention to how the locus of power in an institution such as a school is located primarily within adults, those in authority, and those who hold access to resources. These hierarchical patterns of power replicate wider unequal relations of power in society that serve to marginalise the voices and expressions of those less powerful (such as children). While student voice initiatives consciously attempt to disrupt these imbalances and can succeed, there is a tendency for covert expressions of power to still lead to regulation, social control, and restriction rather than emancipation, democracy, and freedom (Gallagher 2005, 2008; Giroux 2009).

Post-structural accounts of power are also useful in helping to illuminate how power operates in student voice and citizenship work (Robinson and Taylor 2007, 2013). Rather than viewing power as residing in individuals, Foucault $(1980,1982)$ theorises power as a constellation of relational influences which circulates between individuals in a dynamic and flexible state. Post-structural theories of power draw attention to the hidden ways power operates to steer students into forms of 
social control and compliance as 'schooled subjects', rather than towards more emancipatory goals (Arnot and Reay 2007; Robinson and Taylor 2013). In classroom settings this theoretical lens sheds light on the norms and behaviours that reinforce and legitimise power through social interactions and discourse. For example, Arnot and Reay's (2007) analysis of student voice in a school context—which can involve classroom talk, subject talk, identity talk, and code talk-revealed that the classroom norms and rules of the teacher-student encounter tend to produce a 'schooled voice' in line with expectations on learners as to how they should communicate and what they should say. The production of such 'performances' are created through common classroom practices such as bells and timetables that regulate and discipline young people's actions and behaviours (Jenks 2001). Poststructural theories also look for examples of how certain actions modify others (Foucault 1982) and these reveal moments of resistance, opposition and disobedience resistance (Gallagher 2008).

Rather than assume that young people are fully autonomous or that teachers are fully in control, our study sought to examine how the actions of teachers and students were related to each other. As Jeffrey (2011) argues, we cannot assume that young people carve out spaces of individual assertion independent of adult worlds; instead we need to focus on the deeply social and interrelational (and often intergenerational) nature of participation and agency. These two theoretical approaches therefore provide a critical lens which helped us to examine how both young poeple and adults navigated power relations with school settings when attempting to participate in social action.

\section{Research Study and Methodology}

A mixed methods approach underpinned data gathering during the two years of the project (20152016). The research team comprised a collaborative partnership between four university researchers and five secondary school classroom teachers (Wood et. al., 2017). The aim was to explore teachers' practices and young people's experiences of the personal social action achievement standards in Senior Social Studies, from the National Certificate of Educational Achievement (NCEA) in New Zealand, and to identify strategies and approaches that would support students to participate actively in critically informed social action. Two of the university researchers made regular visits to the five schools involved in the project to talk with teachers, observe students during their social action projects, and conduct a total of 12 focus group interviews with students in Years 11-13 (ages 15-18) $(n=93)$. The research team also jointly analysed data, shared new points of learning from the practitioner inquiries, and reviewed emerging research findings.

The schools and teachers involved in this research into Senior Social Studies achievement standards were purposively selected. The five teachers were experienced practitioners who had prior experience of facilitating learning in relation to the personal social action standards undertaken by students as part of the national assessment and credentialing system in New Zealand. The schools were diverse in terms of the ir socio-economic status, location (provincial and urban), and student 
population (ethnic ity). This diversity enabled the research team to examine patterns within and across the cohort (Stake 2008). To situate the micro-spaces of the five teachers' practice and students' experiences at the schools within national practice, teachers throughout New Zealand were surveyed through an online survey $(n=141)$ and the NZQA data on participation and attainment in the three NCEA personal social action achievement standards were examined.

The findings reported in this chapter are drawn from the in-class observations and the reported experiences of teachers and students during the case study of implemented practice across the five participating schools. Our focus during data collection was underpinned by our commitment to exploring what teachers taught, as well as the young people's experiences. For example, teachers and students were asked to describe the approaches they were taking during the social action. Comparing students' views across a range of schools with those expressed by their teachers enabled us to identify cross-school patterns and themes (Cohen et al. 2011). These were shared with teachers and together we developed a theoretical framework for social action learning that was then applied and developed further during the second year to analyse subsequent data according to a priori themes (Braun and Clarke 2013). This analys is enabled us to further explore and validate initial findings and postulate about the transferability of practice to different schooling contexts. In the following section we examine themes that emerged in relation to how the process of taking social action occurred in the five school settings.

\section{Taking Social Action}

Our classroom observations, the focus group interviews with students, and on-going discussions with the five teachers drew our attention to the ways in which both teachers and young people navigated aspects of power throughout the process of taking social action. We were particularly interested in examining the balance of power between teachers and students during this process. Broadly, there was a spectrum of experiences in the classrooms in our study. We identified three broad approaches to social action learning: teacher-led, teacher-guided, and student-led. For example, teacher-led occurred where teachers held higher levels of power and control than their students; student-led involved occasions when students possessed significant degrees of direction and control for their learning; and teacher-guided involved a combination of power and control between teacher and learner.

All five teachers employed these three approaches at varying times according to the contexts they were working in. When teachers adopted a teacher-led approach, they tended to use more structured and controlled processes for student social action projects. For example, a teacher might select the societal issue that the students were to explore and take action on and provide resources, teaching, and other inputs-guest speakers, field trips, and appropriate audio-visual resources- to heighten students' awareness of the issue. Some students expressed how they appreciated this approach as they felt well supported as it gave them more guidance and enabled them to make 
community connections. For example, after meeting representatives from the Red Cross at school, one student explained how this enabled her to connect more with such people in the community as "you are not doing something completely random in the community that you have no connection or association with" (16 years). However, other students did not enjoy this level of teacher-directed learning. As Ben (18 years) articulated:

Like this was kind of imposed on us, we didn't get any choice this year whereas last year we got to choose our charity [to fundraise for]. Whereas this year we got a set one [social issue]. I mean it gives us all the substance of what we have to do but at the same time I feel I don't feel as emotionally charged about it.

Maria (17 years), in the same class, commented 'It's obviously easier to teach if you just give a set topic in class with one issue but I think when you get to choose it [the social issue] yourself you get more [fired up about it]."

At the other end of the spectrum, students held a higher level of control and direction of aspects of their social action process if they were enabled to select their own social issue and direct significant parts of their social action themselves. Examples of such student-led activities included: contacting community members to arrange interviews; creating petitions; and talking to media. While for many this led to high levels of engagement in their chosen focus, others were frustrated at the lack of guidance. For example, Angie (17-years) described how her group struggled to even find a significant social justice focus for their social action and wished they had more teacher input or guidance, especially as their assessment required a policy focus:

\footnotetext{
Well, our one was a bit of a flop. It didn't go very well ... I think actually the biggest thing that we found was we weren't very passionate. Like my group wasn't really passionate about anything in the community and the fact that we had to limit it to the community was quite hard. Yeah, we could do something like that, but we couldn't think of anything proper so ... it did kind of turn out to be something that didn't really properly link to an actual policy and I think that's where we went really wrong.
}

Angie went on to describe how when they approached the Senior Management Team in the school for permission to circulate their surveys and send emails, they were told "no", "which was quite frustrating". Angie concluded that she wished her teacher had given her group better advice at the start and given them the opportunity to see or hear what other students had proposed for their social actions.

Our analysis of some of the frustrations (especially for older high school students) of the extremes of both teacher-led and student-led approaches pointed us to a more middling position: a teacher-guided approach. However, this was a very complex position to articulate and describe as we 
found that the actions of teachers and students were constantly intersecting through tightly connected and shifting exchanges of power-sharing. High levels of trust underpinned such an experience where teachers actively supported their students. This meant at times "letting the students take initiative and sort out problems for themselves" (teacher interview), yet at other times taking a much more involved role. In addition, we noted that while the initial steps in the process of students taking action took place in planned lessons during school, most students then undertook considerable work outside the school. For example, students connected with key members of their local community interviewed people, used community resources such as libraries and archives, and undertook many aspects of the social action outside of school (such as displaying information boards, fundraising, organising petitions, talking to media, and writing to local body or central government politicians). Therefore, it wasn't only teachers who were involved in these social action programmes, but members of the community and key adults (including parents) who played a role in enabling and supporting student action.

This led us to a much closer examination of the exchanges of power between students and adults which we illustrate in the following two case studies. In both cases we outline examples of mediated and negotiated partnerships of power-sharing between the teachers, strategic adults and students at two of our research schools. In both cases, students were in Year 13, ages 17-18, and working on the Level 3 NCEA achievement standard that requires students to Examine personal involvement in a social action(s) that aims to influence policy change(s) (NZQA n.d.).

\section{1 'We're actually allowed to go out and do something': Community engagement}

Kahikatea College ${ }^{3}$ is situated in a mid-sized provincial town in New Zealand. Tina, the teacher at this school who was involved in our study, was a passionate advocate for social studies and social action. Her approach was to create well-supported experiences of community engagement that involved a balance between teacher-led approaches, by setting up the foci of students' social action, followed by student-led approaches of planning social action and communicating directly with community and political members. For example, at the start of the social action focus, she invited local Members of Parliament (MPs) and representatives of community groups (such as the Red Cross) into the school to talk to the students. This quickened students' attention to social and political issues and allowed her to provide teaching support for students who struggled to choose and plan social action. She also had developed a 'staged by age' approach to social action which involved introducing students to 'easier' forms of social action at the junior end of the high school (ages 13-14), and then building upon these experiences to become more 'political' and engaged at the national level of politics by the time they were senior students (ages 17-18). For example, in Year 11 (ages 15-16) students often undertook fundraising to support social causes, and in Year 12 (ages 16-17) enacted closer connections with

\footnotetext{
${ }^{3}$ Schools have been given pseudonyms.
} 
community organisations (including volunteering). By year 13, students undertook a stronger focus on national policy and international issues. Across all these foci, Tina focused strongly and systematically on creating awareness and knowledge about the issues. For example, she encouraged students to create educational information boards to share their learning with members of the community. With the rise of social media, she also encouraged students to use various media platforms to disseminate their messages:

The main message is that social media serves to amplify students' actions (more exposure) but that it can also be used strategically to communicate information and then link to other forms of social action (e.g., petitions).

This supported students to construct robust knowledge about their selected social issues so they could engage with members of the public in meaningful ways and develop personal agency. As students gained more experience in taking social action, they could then move away from more structured teacher-led learning to less structured student-led approaches.

As part of her commitment to creating a climate of enhancing student voice and participation in her school, Tina had also managed to establish a social action prefect on the Student Leadership Committee. This role helped to cultivate a culture where student voice and social action was a norm and was "definitely encouraged, students can do it if they want to" (focus group member). The Social Action Prefect in 2016 was a participant in the focus group discussions. She described an outwardlyfocused school that took part in a wide range of whole-school social action initiatives (such as Red Nose Day, Pink Shirt Day, and World Vision's 40 Hour Famine) that had been organised through the Student Council. The school also actively supported many community-related student social action projects that had been instigated through the Senior Social Studies programme. "Our school knows when it's social action time. They understand it."

The students described how this culture and the incremental decrease in the role of the teacher input made it easier for them to take ownership of their social actions in Year 13. Students reported that they could draw on their own (or other students') learning from earlier years to enhance actions that needed to be more 'political' and might involve contacting MPs and liais ing with other members of the community. Two students (aged 17-18) reflected together that their cumulative prior experiences and Tina's actions had made the final year easier, even when they were faced with having to focus on community, regional, or national level issues:

Miriama: I think in a way it's got harder but, in a way, it's got easier. So, it's harder in respect to that you're not [just] going out and selling cupcakes.

Sophie: You've actually like got to do like the research and everything like that. 
Miriama: You've actually got to do a policy and have a background knowledge. Easier in the respect that if you've done it the previous two years, it's easier.

While some students worked on school-based polices such as gender-neutral toilets or an enhanced curriculum for indigenous Māori students, the majority focused on issues in the local community that mirrored significant societal issues nationally, for example, poverty (provision of school lunches for children who turned up to school hungry), domestic violence, supporting refugee settlement, issues relating to mental health and suicide, and the need for a Living Wage. To enable students to engage with members of their community, Tina had a long-standing relationship with the local librarian in the town who encouraged students to display the ir social issue information boards, to host petitions, and to talk to members of the public. The library provided students with an appropriate place to interact with the public and share their learning about taking social action. For example, two students described how displaying their information board on an opposition MP's Bill in this library helped them to canvas support for their action and collect signatures for their petition:

\footnotetext{
Gina: We talked about the Bill and the effects of it and we sort of like talked to people individually and they would sign if they agreed.

Sophie: They could leave their email address or their normal address if they felt co mfortable enough.
}

School rules and polic ies, however, presented several challenges for students' social action plans and their wide use of this public library. While it was about 10 minutes' walk from the school, students were not generally allowed to leave the school grounds during school hours without extensive health and safety forms being completed. As access to the library was vital for their research, and the dissemination of their social action, Tina devised systems that enabled her students to leave the school grounds in a safe way that did not get them in to trouble. This point of public engagement for the students was highly valued as it contributed to their developing personal agency and engagement in authentic learning experiences. As Miriama articulated:

\footnotetext{
It's really nice getting out into the community and it's also that you've actually got that one onone-contact with people and say if someone tells you something of their like opinion or anything like that, you can use that in your assessment as primary evidence.
}

\section{2 'We are voices for children': Presenting in Parliament}

Our second illustration re lates to a specific event where a group of students presented a submiss ion to the Select Committee in Parliament following their social action project in school. This case illustrates the integral role of the teacher, yet also the conviction and courage of students to take an active role in a Parliamentary process. 
Pōhutukawa College is a medium-sized co-educational college in a relatively affluent community in a small urban centre. This school had less of a tradition of social action than Kahikatea College, but the teacher, Suzie, was keen to establish higher levels of student voice and participation in the school. To equip the students who arrived in Year 13 without much prior experience of social action, Suzie supported their choice of issues by providing an initial list of six societal issues linked to national-level policy that they could potentially explore to align with curriculum requirements. She also encouraged their critical thinking and engagement through several 'hooks' that aimed to inspire students to get involved. She had also constructed some structured templates that included a list of evaluative questions (e.g., "Does this issue affect many people or a few?") which students needed to work through to ensure their research and social action process was rigorous.

Students conducted some initial research on these issues to elic it information that would help them to decide which issue they would focus on. A group of five students decided to focus on a Bill before Parliament that sought to legislate for landlords to maintain a minimum standard for their rental properties. Called the Healthy Homes Bill, the then Leader of the Labour Party, Andrew Little, had drafted this Private Members' Bill and it had been selected by ballot for debate. The students worked as a group to research the background to this Bill, the conditions of housing in New Zealand today and, in particular, how children's health and wellbeing were being affected by growing up in poor quality housing. One of the group members, Katie, explained that while poor quality housing did not affect any of them directly, this issue "stuck with us and knew we could help future leaders and children of New Zealand who do deal with this issue of poor quality housing. We are the voices for them."

Using the information that they had gathered during their research, the group's social actions involved writing a letter to the Opposition Leader Andrew Little to explain their support for his Bill, collecting signatures on a petition to support the Bill, and running a campaign to create greater awareness through gathering views from various levels of the school community (e.g., a workshop with a Year 9 class). Later, this group of students became aware that the Bill had been drawn to go to the Select Committee in August 2016. Suzie extended the formal assessment submission date to enable this group to add to their social action to include a formal submission to the Select Committee. Before becoming a teacher, Suzie had worked for the Select Committee Office so she encouraged these students to tick the box: "I will submit in person to the Select Committee". Coincidentally, one of the students met Andrew Little at a Labour Party function in the region and he encouraged her to let him know if her group would be presenting at the Select Committee. Everyone was surprised and nervous when they were given a date and time to present their submission in person. With Suzie's support these students prepared their oral submission. The ir school principal showed his support by also attending the Select Committee hearing (see Figure 1). 
Students described the process of presenting to the Select Committee as "very nervewracking. We weren't exactly sure how it would go down." Even the prestige of the buildings and the "number of people in suits" was intimidating. As Conrad reflected following the submission:

A lot of the things that I said I thought that they were a little bit underwhelming, so to speak, because I didn't feel as though I was quite professional enough for the occasion. Especially considering that I'm 17 and most of them are double my age ... more experienced and so on.

When reflecting on this experience, however, these students felt it was a highly positive experience as they received warm support from the then Members of Parliament Andrew Little and Jacinda Ardern (now Prime Minister of New Zealand); as Katie said "I could tell they loved having us there." In addition, the chair of the Select Committee provided some encouraging feedback to them on the value of young people presenting their views in this forum, yet still asked the students some rigorous questions during the ir submission. This caused the students to subsequently express concern that they had not undertaken deep enough research into the issue. While at Parliament, the students and their teacher also got the opportunity to vis it the then Labour Leader's office and, as they were leaving the Parliament building, the students were interviewed by a reporter from a major daily newspaper. The students reported that they felt well supported by adults - especially their teacher, school principal, and the aforementioned politicians. They felt the skills and knowledge that they developed during this learning would help them confidently undertake similar actions in their adult lives.

\section{Discussion}

Our analysis in these two illustrations is not intended to undermine or reduce the impact of young people's actions. Instead, we agree with Fielding (2007) that there has been at times "too sharp and too exclusive a focus on the standpoints of young people" (p. 304). This attention has celebrated young people's participation, but often at the expense of recognising significant and powerful roles adults play_especially in the context of regulated spaces such as schools (Bartos 2015; Fielding 2007; Wyness 2013). In both these examples it was almost impossible to extricate the role of the teacher entirely at any stage of the social action process. Yet, in both examples, students had good levels of independence and autonomy over aspects such as their selection of social issues (with some guidance from the teacher), the nature of their actions (such as choosing to write a letter or petition), and their selection of community and government members they communicated with. Instead of analysing this as a process that was student-led or teacher-led as many participation models would have us do, the intersecting contributions of students and teachers and the relational sharing of power interested us.

Teachers were in the picture at all stages of the process and involved to a greater or lesser extent. While the level of the ir involvement may have waxed and waned through the process (see Mutch et al. 2016), this reflected a dynamic exchange state of power relations (Foucault 1980) which were 
mediated between teachers/adults and students. For example, Suzie's provision of a set of issues for students at Pōhutukawa College to choose from gave some structure to the students' choices. Yet this was balanced by giving students freedom to set up their plan of social action to suit their personal strengths and goals. Teachers also provided strategies for community engagement, such as linking to the library as a key site for interaction with the public at Kahikatea College, and opportunities to connect with key people in the community that built upon relationships that were not completely random. Teachers discussed how this process involved their letting go of power and control at times, to allow students to take risks and show initiative, while at other times intervening to ensure students had strong levels of learning and engagement. For example, Tina held a strong commitment to get students to disseminate their own knowledge and research to the wider community, so she worked hard to enhance her students' depth of understanding. Mitra (2005) describes this process as a balancing act that allows youth the space to stumble at times whilst also ensuring they succeed more often than they fail.

We can see that young people's partic ipation in citizenship action and student voice is much more than an oppositional model of power in which adults must relinquish power in order for young people to participate. Instead, the story is much more complex. Critical theoretical approaches helped to reveal how teachers who held generally greater levels of power, authority and know ledge used this to equip and empower their students to greater levels of agency. For example, in the second case, the strategic knowledge held by Suzie about the Select Committee where she had worked gave the students far more confidence to go ahead and present their submission to the committee in person. Beyond the teachers, we were surprised to notice how many other adults also played a significant role in supporting and encouraging students. In the Select Committee case, students were encouraged by welcoming encounters with MPs Andrew Little and Jacinda Ardern which meant that despite the nerves, these students viewed this as a positive experience. Later, they recognised the value of this support as, whilst they felt intimidated by the place and process, they considered they could take such actions again in the future. The creation over many years of a school climate at Kahikatea College that supported social action also demonstrates a type of power-sharing which equipped students' participation. What we want to highlight is that due to this highly regulated nature of schools and the power asymmetries that exist, a much greater focus on power sharing needs to occur. Teachers needed to actively share power to create opportunities for student participation and agency and enable a more meaningful citizenship experience.

An understanding of power as relational and dynamic through post-structural theory also helped to illustrate how both teachers and students enacted forms of resistance in order for greater levels of participation to occur. Whilst both colleges that feature in this chapter had supportive environments for student social action, there were still constraints imposed upon students, such as restrictions in leaving the school site at Kahikatea College, in this case, Tina's agency in finding ways for students to leave the school grounds at Kahikatea College. Power therefore was not something 
teachers held, and students did not, in a zero sum game where some have to 'lose' for others to 'win' (Foucault 1982); instead, social action was a partnership with commitment from both students and teachers that included, at times, creative and radical forms of resistance. If we view power as something that is exercised or an action, rather than only something which is held, we can also see how students themselves created spaces for agency and resistance (such as showing creativity, resilience, and courage as they connected with adults, including community members, MPs etc. many years older than themselves) in order to generate new constellations of influence (Foucault 1980).

The cases discussed here and others from our study (e.g., see Wood et. al, 2017) demonstrate that student voice and agency need to be understood as a negotiation between young people, young people and their peers, and between school and community members, in dynamic ways:

\footnotetext{
In each of these ways of working the power relations are different, thus not only enabling or prohibiting the contributions of one side of the partnership but also influencing the potential synergy of the joint work, thereby affecting the possibility of both adults and young people being able to listen to and learn with and from each other. (Fielding 2011, p. 67)
}

Fie lding (2006) refers to this as a kind of "radical collegiality" (p. 308), which involves going beyond a reciprocity of topic and technique to teachers and young people learning from each other in holistic, co-constructive and collaborative partnership, rather than one party using the other for often covert ends. These types of processes and relationships must therefore involve a certain amount of critical training or education as students and staff engaging in student voice work must have the theoretical tools to understand the pervasive effects of power and knowledge in order to resist these (Taylor and Robinson 2009). A useful starting point for schools contemplating student voice work could be to use these two case studies for discussion and critical application to their own contexts.

In conclusion, we return to the models of participation discussed earlier that help frame this research. These models are useful as they provide a way to analyse and evaluate participatory and student voice projects and we have used them extensively in our own research and teaching. These models, however, do require reading with a great deal more complexity than they are normally given. Our intention is not to dismiss the use of these models, but instead to recognise their limitations and the need to more fully engage with prior landscapes of power that operate in school spaces and the highly dynamic state of intergenerational interplay in participatory projects. In fact, a close reading of both Hart's (1992) and Fielding's (2007) models arrive at a very similar point to our argument in this chapter - that is, that the highest rung isn't student autonomy as many expect. Instead, Hart outlines a position of 'child-initiated shared decisions with adults' and Fielding describes a 'pattern of partnership' between adults and students that is intergenerational and involves learning together as a living democracy. 
We recognise that we still have a long way to go to truly experience radical collegiality in schools, but nonetheless we can see some of this in our study. Recognising the highly complex hierarchies of power within highly regulated school sites and the difficulty of enabling students to experience a genuine experience of student voice and citizenship, we affirm Hart's (1992) statement when he says: "We need people who are able to respond to the subtle indicators of energy and compassion in teenagers" (p. 14). Our research confirms and explains the importance of student voice in education, involving learning together as a living democacy, towards a dynamic notion of partnership, where we argue that power-sharing is key to student participation and student voice. 


\section{References}

Arnot, M., \& Reay, D. (2007). A sociology of pedagogic voice: power, inequality and student consultation. Discourse: Studies in the Cultural Politics of Education, 28(3), 311-325. doi.org/10.1080/01596300701458814

Arnstein, S. (1969). A ladder of citizen participation. Journal of the American Institute of Planners, 35(4), 216-224. doi.org/10.1080/01944366908977225

Barber, T. (2009). Participation, citizenship and well-being: engaging with young people, making a difference. Young, 17(1), 25-40. doi.org/10.1177/110330880801700103

Bartos, A. E. (2015). Children and young people's political participation: A critical analysis. In K. P. Kallio, S. Mills, \& T. Skelton (Eds.), Politics, citizenship and rights (pp. 1-15). Singapore: Springer.

Braun, V., \& Clarke, V. (2013). Successful qualitative research: A practical guide for beginners. London: Sage.

Cohen, L., Manion, L., \& Morrison, K. (2011). Research methods in education. New York: Routledge.

Cook-Sather, A. (2014). The trajectory of student voice in educational research. New Zealand Journal of Education Studies, 49(2), 131-148.

Faulks, K. (2000). Citizenship. London: Routledge.

Fielding, M. (2004). Transformative approaches to student voice: theoretical underpinnings, recalcitrant realities. British Educational Research Journal, 30(2), 295-311. doi:10.1080/0141192042000195236

Fielding, M. (2006). Leadership, radical student engagement and the necessity of person-centred education. International Journal of Leadership in Education, 9(4), 299-313. doi:10.1080/13603120600895411

Fielding, M. (2007). 'Beyond voice': new roles, relations and contexts in researching with young people. Discourse: Studies in the cultural politics of education, 28(3), 301-310. doi.org/10.1080/01596300701458780

Fielding, M. (2011). Patterns of partnership: Intergenerational learning and democratic fellowship. In N. Mocker \& J. Sachs (Eds.), Essays in honour of Susan Groundwater-Smith. Dordrecht: Springer.

Foucault, M. (1980). Power knowledge: Selected interviews and other writings 1972-1977. NY: Harvester Wheatsheaf.

Foucault, M. (1982). The subject and power. Critical Inquiry, 8(4), 777-795. doi.org/10.1086/448181

Gallacher, L., \& Gallagher, M. (2008). Methodological immaturity in childhood research? Thinking through participatory methods. Childhood, 15,499-516. doi.org/10.1177/0907568208091672 
Gallagher, M. (2005). Producing the schooled subject: Techniques of power in a primary school. (doctoral thesis). The University of Edinburgh, Scotland.

Gallagher, M. (2008). 'Power is not evil': rethinking power in participatory methods. Children's Geographies, 6(2), 137-150. doi.org/10.1080/14733280801963045

Giroux, H. (2009). Introduction: Democracy, education and the politics of critical pedagogy. In P. Mclaren \& J. Kincheloe (Eds.), Critical pedagogy: Where are we now? (pp. 1-5). New York: Peter Lang.

Hart, R. (1992). Children's participation: From tokenism to citizenship (Innocenti Essays No. 4). Florence: UNICEF Innocenti Research Centre.

Holt, L. (2004). Children with mind-body differences: performing disability in the school classroom. Children's Geographies, 2(2), 219-236. doi.org/10.1080/14733280410001720520

Invernizzi, A., \& Williams, J. (2008). Children and citizenship. London: Sage.

James, A., Jenks, C., \& Prout, A. (1998). Theorizing childhood. New York: Teachers College Press. Jeffrey, C. (2011). Geographies of children and youth II: global youth agency. Progress in Human Geography. 36(2), 245-253. doi:10.1177/0309132510393316

Jenks, C. (2001). The pacing and timing of children's bodies. In K. Hulrqvist \& G. Dahlberg (Eds.), Governing the child in the New Millenium (pp. 68-84). New York: RoutledgeFalmer.

Kennedy, K. (2007). Student constructions of 'active citizenship': what does participation mean to students? British Journal of Educational Studies, 55(3), 304-324. doi.org/10.1111/i.14678527.2007.00381.x

Lundy, L. (2007). 'Voice' is not enough: conceptualising Article 12 of the United Nations Convention on the Rights of the Child. British Educational Research Journal, 33(6), 927-942. doi:10.1080/01411920701657033

Mayes, E., Bakhshi, S., Wasner, V., Cook-Sather, A., Mohammed, M., Bishop, D., .. McLaughlin, C.. (2017). What can a conception of power do? Theories and images of power in student voice work. International Journal of Student Voice, 2(1). https://ijsv.psu.edu/?article=what-can-aconception-of-power-do-theories-and-images-of-power-in-student-voice-work

McLaughlin, T. (1992). Citizenship, diversity and education: A philosophical perspective. Journal of Moral Education, 21(3), 235-250. doi.org/10.1080/0305724920210307

Mitra, D. L. (2005). Adults advising youth: leading while getting out of the way. Educational Administration Quarterly, 41(3), 520-553. doi:10.1177/0013161x04269620

Mutch, C., Perreau, M., Houliston, B., \& Tatebe, J. (2016). Teaching social studies for social justice: Social action is more than 'doing stuff'. In M. Harcourt, A. Milligan, \& B. E. Wood (Eds.), Teaching social studies for critical, active citizenship in Aotearoa New Zealand (pp. 82-101). Wellington: NZCER.

Nelson, J., \& Kerr, D. (2006). Active citizenship in INCA countries: Definitions, policies, practices, and outcomes. London: NFER/QCA http://www.inca.org.uk/pdf/Active_Citizenship_Report.pdf. Accessed August 2007. 
New Zealand Qualifications Authority [NZQA]. (n.d.). National Certificate of Educational Achievement [NCEA] Social Studies subject resources.

http://www.nzqa.govt.nz/qualifications-standards/qualifications/ncea/subjects/socialstudies/levels/. Accessed March 2017.

Pearce, T. C., \& Wood, B. E. (2016). Education for transformation: an evaluative framew ork to guide student voice work in schools. Critical Studies in Education, 1-18 (iFirst). doi:10.1080/17508487.2016.1219959

Robinson, C., \& Taylor, C. (2007). Theorizing student voice: values and perspectives. Improving Schools, 10(1), 5-17. doi:10.1177/1365480207073702

Robinson, C., \& Taylor, C. (2013). Student voice as a contested practice: power and participation in two student voice projects. Improving Schools, 16(1), 32-46. doi:10.1177/1365480212469713

Shier, H. (2001). Pathways to participation: openings, opportunities and obligations. Children and Society, 15(2), 107-117. doi.org/10.1002/chi.617

Skelton, T. (2007). Children, young people, UNICEF and participation. Children's Geographies, 5(12), 165-181. doi.org/10.1080/14733280601108338

Stake, R. E. (2008). Qualitative case studies. In N. Denzin \& Y. Lincoln (Eds.), Strategies of qualitative inquiry (pp. 119-149). London: Sage.

Taylor, C., \& Robinson, C. (2009). Student voice: theorising power and participation. Pedagogy, Culture \& Society, 17(2), 161-175. doi.org/10.1080/14681360902934392

Thomas, N., \& Percy-Smith, B. (2010). Introduction. In B. Percy-Smith \& N. Thomas (Eds.), A handbook of children and young people's participation (pp. 1-7). Oxon: Routledge.

Thomson, P., \& Holdsworth, R. (2003). Theorizing change in the educational 'field': re-readings of 'student participation' projects. International Journal of Leadership in Education, 6(4), 371391. doi.org/10.1080/1360312032000150751

Treseder,P. (1997). Empowering children and young people: Training manual: Promoting involvement in decision-making. London: Save the Children.

Westheimer, J., \& Kahne, J. (2004). What kind of citizen?: The politics of educating for democracy. American Educational Research Journal, 41(2), 237-269. doi.org/10.3102/00028312041002237

Wood, B. E., Taylor, R., \& Atkins, R. (2013). Fostering active citizenship in social studies: Teachers' perceptions and practices of social action. New Zealand Journal of Educational Studies, 48(2), 84-98.

Wood, B. E., Taylor, R., Atkins, R., \& Johnston, M. (2017). Creating active citizens? Interpreting, implementing and assessing 'personal social action' in NCEA social studies: Final Report. NZCER: Wellington. http://www.tri.org.nz/sites/default/files/projects/TLRI\%20Summary_Wood\%28v2\%29.pdf Accessed April 2017. 
Woodhead, M. (2010). Foreword. In B. Percy-Smith \& N. Thomas (Eds.), A handbook of children and young people's participation: Perspectives from theory and practice (pp. xix-xxii). Oxon: Routledge.

Wyness, M. (2013). Children's participation and intergenerational dialogue: bringing adults back into the analysis. Childhood, 20(4), 429-442. doi:10.1177/0907568212459775 